\title{
Leipzig 2004
}

\author{
By Dorothea Moritz
}

Spring 2005 Issue of KINEMA

\section{LEIPZIG INTERNATIONAL FESTIVAL FOR DOCUMENTARY AND ANIMATION FILMS 2004}

At the closing of the awards ceremony for the $47^{\text {th }}$ Internationales Leipziger Festival Für Dokumentar- und Animationfilm (19-24 October 2004), Boris Baberkoff sat on stage and played on his cello Bach's "Fifth Suite in C-Minor." Boris, incapacitated in 1998 by a severe stroke in New York, had "beaten the odds" and was back in form. His wife, Katarina Peters, had the strength to remain at his side. Her survival strategy was to make use of a video DV camera as a diary. Thus Am seidenen Faden (Stroke, Germany) is a film that radiates courage. Katarina also confides her worries on video: Will her beloved husband remain a invalid? Will they have enough money to pay the bills? But the pair are indeed fortunate. Boris is endowed with an admirable will to live. A neatly structured and edited documentary, Katarina Peters's Stroke deserved its armful of prizes: a Silver Dove, the Ecumenical Prize, the FIPRESCI (International Critics) Prize, and the Youth Jury Award.

In Bach-town Leipzig the Golden Dove for Long Documentary was awarded to Thomas Riedelsheimer's Touch the Sound (Germany-UK), an enchanting film about the world of sound as experienced from the inside by the nearly deaf solo-percussionist Evelyn Glennie. Riedelsheimer, director of the award-winning Rivers and Tides - Fluss der Zeit, is now in line for another major international award: following its success at the Locarno film festival, Touch the Sound has been nominated for a European Film Award. A portrait, yet much more, of the fascinating and talented percussionist Evelyn Glennie, a woman who is almost completely deaf. One can not only hear sounds, she says, but also feel them - and this in the city of Johann Sebastian Bach!

This exceptional documentary depicts how a nearly deaf sound artist uses what she calls her "sixth sense" - her body as a resonating space - to replace her lack of hearing. When she was twelve years old, the doctors said that soon she would not be able to hear a thing. But that did not hinder her from becoming an exceptional musician, one who has accomplished the impossible. "I hear differently than others," she says. She feels the rhythms of the city, the rhythm of nature, with her entire body. Everything serves Evelyn Glennie as a sounding-board: not only drums, the tam-tam-gongs, the xylophone, but also tables, walls, boards, plates From a prudent distance Riedelsheimer sensitively observes the performing artist. As evidenced in Stroke, Touch the Sound shows how much can be achieved, given the will to become a musician. And the Leipzig festival rightly opened with this remarkable audience film.

The festival also opened on another high note. Fred Gehler, who with a sure hand had guided the DOKfestival over the past decade, was awarded an Honorary Golden Dove. As cultural spokesman Georg Girardet, among others, stated at the ceremony, Fred Gehler always safeguarded the artistic integrity of the festival by refusing to follow the current stylistic trend. The Big Band of the Leipziger Musikschule "Johann Sebastian Bach" accompanied the festivities.

Claas Danielsen, the new director of the $47^{\text {th }}$ Leipziger DOKfestival, together with his team, have met the challenge and stood the test. Indeed, with an audience of over 24,000 , an increase of $30 \%$ over last year, they should be more than pleased. The turnout was particularly strong for the new section: a welcomed German Documentary Competition. As for the International Animation Competition, this too saw every program (as usual) packed to the brim, thanks to the programming finesse of Otto Alder. This year's Golden Dove for Animation was awarded to Chris Landreth's outstanding Ryan (Canada). Ryan Larkin, whose Walking (1968) had once been nominated for an Oscar, is today a social case, a gentleman panhandler, so to speak. In his 14-minute portrait Chris Landreth aptly demonstrates how closely animation and documentary interlink with one another. Landreth also pays homage to his prominent colleague, a great artist and one of the pioneers of Canadian animation, in a personal tribute imbued with love, friendship, and sadness.

Cineastes could enjoy the festival's patented retrospective treats. "Volker Koepp: People and Landscapes," in particular, was a highlight not to be missed. Organized by the Bundesarchiv-Filmarchiv (German Film 
Archive), the retro embraced all his documentaries from 1973 to the present under the rubric "Films from Wittstock to Czernowitz." Der Wittstock-Zyklus (1975-1997), a cycle of seven interlocking documentaries, chronicled the life and times of female workers in a textile factory just north of Berlin that had employed up to two thousand young women during GDR times. As for Koepp's awarded Czernowitz documentary, Herr Zwilling und Frau Zuckermann (1999), photographed by Thomas Plenert, it's a poignant portrait of an elderly pair who had witnessed horrific events during the war. Unfortunately, the documentaries in this retro were not translated into English, in contrast to other entries either translated into English or already possessing English subtitles - a big win, to say the least! Another retrospective highlight was "Carte Blanche / Fred Gehler," a tribute to the programming director of DOKfilm Leipzig over the past ten years. In his series Gehler focused on some legendary personalities in the field - for example, Luis Buñuel's L'âge d'or (France, 1930), one of Gehler's favourite filmmakers. He also throws light on some unknown chapters in the history of the DOKfestival - how many Leipzig faithful would remember Lutz Dammbeck's L'Hommage à la Serraz (GDR, 1982), a documentary that had once celebrated an unauthorized premiere in the Casino Kino at the Leipzig festival.

ARTE, the French-German cultural channel, presented a special series on humour in the documentary film, titled "Life Is Terribly Funny!" Needless to say, this amusing baker's dozen was a big hit with the public - and I finally had the chance to see Ulrich Seidl's Mit Verlust ist zu rechnen (Losses to Be Expected, Austria, 1982). Set on the Austrian-Czech border, this tongue-in-cheek tale about a widower who has his eye on a widow in the next village is faced with a dilemma: the border that separates the couple! Some film-and-festival highlights were also enjoyed in the Polish Institute. A bonus cultural partner over the past years, this is a favourite festival venue for discussions and roundtables, particularly on the historical side. This year, the Polish Institute presented a program of classic Polish documentaries - among them Jerzy Bossak's Warszawa 1956 (Warsaw 1956).

Über die Grenze - Fünf Ansichten von Nachbarn (Across the Border - Five Views from Neighbours) scored as a genuinely entertaining compilation of short films by Central European filmmakers in five new EU memberstates (Czech Republic, Hungary, Poland, Slovakia, and Slovenia). As a collective two-hour statement from the respective countries the directors (Pawel Lozinski, Jan Gogola, Peter Kerekes, Robert Lakatos, Biljana Čakić-Veselić) touch on such "border topics" as political exiles, prostitutes, asylum seekers, customs inspectors, tramps and drug-dealers to create a common meaningful "European film" woven from autonomous vignettes that reflect individual concerns. Across the Border was awarded two prizes: the Golden Dove for Best Short Documentary (as a series) and the Mitteldeutscher Rundfunk Film Prize.

From Korea came one of the festival's most memorable entries: Hosup Lee's And Thereafter (USA-Republic of Korea), awarded the Silver Dove for Best Long Documentary, ex aequo with Stroke. The story of a South Korean war bride, one of ten thousand who married GIs shortly after the Korean conflict, the candid 76-yearold Young-Ja Wike looks back on a scarred family history: an unfaithful and abusive husband and grown children who only visit when they need money. A shattering story of a wartime destiny, And Thereafter sensitively depicts a broken life from a frank perspective - a penetrating psychogram. The pulse of North Korea was taken in Pieter Fleury's North Korea, A Day in the Life (Netherlands). Here the Great Leader, Kim Jong Il, is seen and heard everywhere in the life of a worker at a textile factor as though his presence is an entirely "normal" function of living and working! And in Dong-Won Kim's Repatriation (Republic of Korea) the director, known as the godfather of independent Korean filmmakers, has documented over a stretch of some twelve years the lives of two North Koreans, who, as political prisoners, had spent 30 years in a South Korean prison on a charge of espionage. Refusing to submit to a "program of conversion," they were eventually repatriated to North Korea in 2000.

A pity that Orzu Shapirov's Runaways (Tajikistan), shot with a video camera, was overlooked by the international jury. The story of Afghan villagers who are forced to flee the bombing in the north to take refuge on uninhabited islands on the Pianj River bordering Tajikistan, these refugees have witnessed the destruction of their homes and are now barely existing without a roof over their heads. Carrying everything they have in sacks on their backs and on donkeys, their exodus is across arid deserts and flooded rivers. In their faces, and those of their children, you can sense the helplessness of their situation and an incomprehension of the reasons for their ordeal. A documentary without dialogue or commentary, the message in Runaways is written on the harsh wind that has driven them to this precarious perch in a hostile landscape. 
None of the entries in the International Competition, nor those in the German Competition, disappointed. Indeed, every documentary entry was worth seeing and discussing, and quite a few of them would have received my vote for a festival Dove. I particularly liked Douglas Wolfsperger's Die Blutritter (Riders of the Sacred Blood, Germany), directed by the same filmmaker who gave us the memorable Bellaria (2001), about old-timers frequenting a repertory cinema in Vienna that specializes in movies from the golden age of German and Austrian talkies. The focus this time is on a religious custom that takes place annually since 1094 in the village of Weingarten in Swabian Germany. There, on the Friday following Ascension Day, three thousand riders participate in the "blood ride" custom: before thousands of spectators they pay honour, as the legend goes, to a relic that contains the Blood of Christ on the Cross. Strikingly lensed by ace cameraman Igor Luther, Douglas Wolfsperger's Riders of the Sacred Blood chronicles an event in this Catholic hamlet listed as the "world's biggest rider procession." Wolfsperger has been invited to ride in the procession next year.

The International Competition was packed with memorable documentary entries. Christian Bauer's The Ritchie Boys (Germany) tells the story of German Jews who had emigrated to the United States, then returned to Europe as American soldiers. Now octogenarians, they recall the time spent at Camp Ritchie in Maryland, where their language skills were augmented by training in psychological warfare before they could finally depart for the European war theatre. Another standout film in the German Competition, Jörg Adolph's Kanalschwimmer (Channel-Swimmers) accompanies three swimmers during their quests to swim across the 20-mile English Channel. The first has already achieved the feat 32 times, the second wants to break the 7 hours, 17 minutes record, and the third is trying "just to do it" for the first time. Similarly, in Klaus Stern's Weltmarktführer - Die Geschichte des Tan Siekmann (World Market Leader - The Story of Tan Siekmann), the focus is on another "achiever" with a drive to match his dream. During the recent dot.com boom, the 30-year-old Tan Siekmann, head of the Biodata company in the ISDN data encryption field, was for a brief spell a billionaire - until the bubble burst and the company went bankrupt. These are fascinating, thrilling stories about people whose lives are scarcely filled with a dull moment.

Russia was strongly represented at Leipzig with a pair of short documentaries. In Vladimir Nepevny's delightful Veselyi Santechnik (Happy Plumber), an entry in the International Documentary sidebar, a sewerworker can recite at will verses from Mayakovsky and Dostoevsky and is just as familiar with the writings of James Joyce! Awarded the Silver Dove for Short Documentary, Pavel Kostomarov and Antoine Cattin's Marnaja zhizn (Life in Peace) (Russia-Switzerland) traces the destinies of a father and son living in southern Russia who have been forced to leave their home due to the war in Chechnya. Emigrating to Russia, they are interrogated by the authorities, can't find their footing in exile, begin to drink and become aggressive anything but a "life in peace"! The images alone in Life in Peace effectively underscore how war can destroy the soul as well as leave behind a trail of agonizing misery.

Further, in regard to the current Russian film revival, the First Prize in the Student Films Competition at the recent International Film Camera Festival "Manaki Brothers" in Bitola was also awarded to a Russian entry: Sergei Ross's Miaso (Meat), about a destitute mother, the widow of a military officer, who prostitutes herself for food to feed her infant son. And, at the Cottbus Festival of East European Cinema, the Main Prize for Best Film was awarded to Guka Omarova's Schiza (Schizo, Russia-Kazakhstan-France-Germany), scripted together with veteran Russian director Sergei Bodrov.

Herewith the dates for next year's Leipzig DOKfestival: 17-23 October 2005. Don't miss it! If you thought this year's crop of documentaries was exceptional, then next year promises to be even better.

\section{References}

\section{AWARDS}

\section{International Competition}

Golden Dove, Long Documentary

Touch the Sound (Germany-UK), Thomas Riedelsheimer 
Silver Dove, Long Documentary - ex aequo

Am seidenen Faden (Stroke, Germany), Katarina Peters

And Thereafter (USA-Republic of Korea), Hosup Lee

Golden Dove, Short Documentary

Über die Grenze - Fünf Ansichten von Nachbarn (Across the Border - Five Views from Neighbours, Austria), Pawel Lozinski, Jan Gogola, Peter Kerekes, Robert Lakatos, Biljana Čakić-Veselić

Silver Dove, Short Documentary

Marnaja zhizn (Life in Peace, Russia-Switzerland), Pavel Kostomarov, Antoine Cattin

Talent Dove - Sparkasse Leipzig Prize

Jerusalem min Elskede (Jerusalem My Love, Denmark), Jeppe Ronde

German Competition

Discovery Channel Film Prize

Berlin Beirut, Myrna Maakaron

European Docuzone Award

Invisible - Illegal in Europa (Invisible - Illegal in Europe), Andreas Voigt

Special Mention

Im Arsch der Welt (In the Back of Beyond), Claus Strigel

Wir leben im einundzwanzigsten Jahrhundert (We Are Living in the 21st Century), Claudia Indehock

International Animation Competition

Golden Dove

Ryan (Canada), Chris Landreth

Silver Dove

Son of Satan (USA), J. J. Villard

Special Mentions

Allerleirauh (Whisper of the Fur-Cone, Germany), Anja Struck

Morir de Amor (Dying of Love, Germany), Gil Alkabetz

Accordéon (Accordion, Canada), Michèle Cournoyer

Other Awards

MDR (Mitteldeutscher Rundfunk) Film Prize

Über die Grenze - Fünf Ansichten von Nachbarn (Across the Border - Five Views from Neighbours) (Austria),

Pawel Lozinski, Jan Gogola, Peter Kerekes, Robert Lakatos, Biljana Čakić-Veselić

ver.di (Media Trade Union) Prize

Bei tempi (Good Times, Italy), Alessandro Cassigoli, Dalia Castel

FIPRESCI (International Critics) Prize

Am seidenen Faden (Stroke, Germany)

Katarina Peters

Ecumenical Jury

Am seidenen Faden (Stroke, Germany)

Katarina Peters

Leipzig Youth Jury Prize

Am seidenen Faden (Stroke, Germany)

Katarina Peters

Mephisto-97.6 Audience Prize

Morir de Amor (Dying of Love, (Germany)

Gil Alkabetz 


\section{Author Information}

Dorothea MORITZ graduated from the State Acting School in Hamburg. She performed on many stages and in TV roles, including the Deutsches Schauspielhaus Hamburg. Currently, she performed literary readings in Brandenburg, Romania, Austria and at the Berlin Cathedral. She has served on numerous juries at international film festivals. Awards (co-recipient): the Polish Ring, presented by Andrzej Wajda and the Association of Polish Filmmakers, and the Freedom Award of the American Cinema Foundation in Los Angeles. 